\title{
Effect of prepartum exercise, pasture turnout, or total confinement on hoof health
}

\author{
R. A. Black, ${ }^{*}$ S. R. van Amstel, $†$ and P. D. Krawczel*1 \\ *Department of Animal Science, The University of Tennessee, Knoxville 37996 \\ †Department of Large Animal Clinical Sciences, The University of Tennessee, Knoxville 37901
}

\section{ABSTRACT}

Lameness is a major welfare concern in the dairy industry, and access to physical activity during the dry period may improve hoof health. The objective of this study was to determine the effects of forced exercise, pasture turnout, or total confinement of dry cows on horn growth and wear and sole thickness. Twenty-nine primiparous and 31 multiparous, pregnant, nonlactating Holstein $(\mathrm{n}=58)$ and Jersey-Holstein crossbred $(\mathrm{n}=2)$ dairy cows were assigned to either total confinement $(\mathrm{n}=20)$, exercise $(\mathrm{n}=20)$, or pasture ( $\mathrm{n}$ $=20$ ) treatments at dry-off using rolling enrollment from January to November 2015. Cows were managed with a 60 -d dry period $(58.5 \pm 5.4 \mathrm{~d})$ divided into faroff (dry-off to 2 wk before parturition) and close-up periods ( 2 wk before projected parturition). Cows were housed in a naturally ventilated, 4-row freestall barn at the University of Tennessee's Little River Animal and Environmental Unit (Walland, TN) with concrete flooring and deep-bedded sand freestalls. Cows assigned to confinement remained in the housing pen. Exercise cows were walked for a targeted $1.5 \mathrm{~h}$ at $3.25 \mathrm{~km} / \mathrm{h}, 5$ times/wk until calving. Pasture cows were turned out for a targeted $1.5 \mathrm{~h}, 5$ times/wk until calving. Hoof growth and wear and sole thickness of the rear hooves were measured on d 2 and 44, relative to dry-off. Data were analyzed using the MIXED procedure of SAS (SAS Institute Inc., Cary, NC). Cranial and caudal horn wear was greater for exercise cows than confinement and pasture cows. Exercise cows experienced more equal rates of horn growth and wear cranially. Confined cows tended to increase sole thickness from d 2 to 44, relative to dry-off. Frequent, short duration exercise on concrete did not impair the hoof health of late-gestation dry cows. Further, exercise may improve overall hoof health, potentially improving cow welfare.

Key words: hoof health, prepartum exercise, lameness, physical activity

Received September 30, 2016.

Accepted April 22, 2017.

${ }^{1}$ Corresponding author: krawczel@utk.edu

\section{INTRODUCTION}

Lameness continues to be a major concern within the dairy industry, with clinical prevalence averaging 30\% and ranging from 5 to $65 \%$ in California and averaging $55 \%$ and ranging from 10 to $85 \%$ in the northeastern United States (von Keyserlingk et al., 2012). Lameness is a welfare concern (von Keyserlingk et al., 2009) because it causes pain (Whay et al., 1998; Shearer et al., 2013), and it also reduces milk production by more than $1 \mathrm{~kg} / \mathrm{d}$ (Kossaibati and Esslemont, 1997; Warnick et al., 2001; Green et al., 2002) and increases culling (Booth et al., 2004). Infectious disease (i.e., digital dermatitis, foot rot) and claw horn disruptions (i.e., white line separation, ulcers, and hemorrhage) can cause lameness. Alternatively, management factors (i.e., concrete flooring, zero grazing, uncomfortable stalls) increase the risk of lameness (Cook and Nordlund, 2009). Although these factors can be controlled to prevent different hoof disorders increasing lameness risk, management factors may be the most easily controlled.

With the majority of cows housed on concrete flooring (55.6\%), few cows have access to softer standing surfaces such as rubber flooring (13.9\%), dirt (20\%), or pasture (5.1\%; USDA, 2010). Concrete flooring was associated with increased incidence of digital dermatitis (48.5\%) compared with pasture $(28.2 \%$; Wells et al., 1999 ) and at least one claw disorder (78 to 81\%) compared with straw yards (57.5\%; Somers et al., 2003), and it can often result in unequal hoof horn growth and wear and heel erosion (Vanegas et al., 2006; van Amstel et al., 2016). Standing and walking on hard solid surfaces (Sogstad et al., 2005; Vanegas et al., 2006) and slippery surfaces (Solano et al., 2015) and walking along poorly maintained or congested cow tracks (Burow et al., 2014; Ranjbar et al., 2016) can have negatively effects leading to lameness. However, offering cows access to softer surfaces may improve hoof health. Housing cows on pasture for 3 wk improved locomotion compared to a total confined control group (Hernandez-Mendo et al., 2007), which may have been related to increased activity because cows housed on pasture are more active than those in confinement 
(Hernandez-Mendo et al., 2007; Legrand et al., 2009; Black and Krawczel, 2016).

Most dairy cattle in the United States are housed in tiestalls, stanchions, or freestall barns with no access to pasture (58.9\%; USDA, 2016). These barns offer no access to exercise outside of traveling to the milking parlor, waterer, feed resources, and social interactions. However, cows given access to exercise 2 or 7 times/ wk tended to have a shorter claw diagonal than nonexercised cows kept in tie-stalls on rubber mats (Loberg et al., 2004). Shorter and steeper claws show less susceptibility to disease (Politiek et al., 1986; Smit et al., 1986) and may be improved with increased physical activity. Therefore, allowing cows access to increased physical activity through pasture turnout may improve hoof health, while walking cows excessively on concrete or hard surfaces may lead to hoof disorders.

These factors may be increasingly important in late-gestation cows in which horn quality is weakened, making them more susceptible to hoof ailments (Kempson and Logue, 1993). Implementing physical activity during late gestation may help to offset reduced horn quality without negative effects on performance. Although studies have determined the effect of different surfaces on hoof health, no studies have examined the effect of the amount of activity on these surfaces on hoof health. Understanding the implications related to regular exercise of cattle, either on concrete or with pasture turnout, will provide insight into the effect of physical activity on hoof health during late gestation. The objective of this study was to determine the effects of exercise, pasture turnout, or total confinement of dry cows on horn growth and wear, sole thickness, and lameness.

\section{MATERIALS AND METHODS}

\section{Animals, Housing, and Management}

Twenty-nine primiparous and 31 multiparous, pregnant, nonlactating Holstein $(\mathrm{n}=58)$ and Jersey $\times$ Holstein crossbred $(\mathrm{n}=2)$ dairy cows were assigned to either confinement $(\mathrm{n}=20)$, exercise $(\mathrm{n}=20)$, or pasture $(\mathrm{n}=20)$ treatments at dry-off using rolling enrollment from January to November 2015. Cows were balanced on parity $(1.8 \pm 0.9)$, projected matureequivalent FCM $(13,831 \pm 2,028 \mathrm{~kg}$ per lactation), and projected calving date. A 60-d dry period (58.5 \pm 5.4 d) was used with cows divided into a far-off group (dryoff to $2 \mathrm{wk}$ before parturition) and close-up group (2 wk before projected parturition or signs of parturition).

Cows were housed in a naturally ventilated, 4-row head-to-head freestall barn with drive-through feed bunk at the University of Tennessee's Little River Animal and Environmental Unit (Walland, TN) constructed in 2011. Deep-bedded sand freestalls were 2.4 $\mathrm{m}$ long and $1.2 \mathrm{~m}$ wide with a 1.2-m-high neck rail positioned $1.7 \mathrm{~m}$ from the curb and a 0.6-m-high polyvinyl chloride tube brisket board placed $1.7 \mathrm{~m}$ from the curb. Fresh sand was added once per week with manure removed from stalls twice daily before milking (0730 and $1730 \mathrm{~h})$. Concrete alleyways had diamond cut grooving with grooves $10.2 \mathrm{~cm}$ apart. Fans turned on automatically when temperatures rose above $23^{\circ} \mathrm{C}$. Throughout the study period, study cows were housed in either pen 1, 2, or 6 (Figure 1), with pens measuring $12.1 \mathrm{~m}$ wide and $19.4 \mathrm{~m}$ long, enclosing 24 freestalls and 26 headlocks ( $0.6 \mathrm{~m}$ wide), and containing 2 waterers, one on each end. Study cows were comingled unless the pen was split into far-off and close-up groups, leaving 12 freestalls and 13 headlocks for each group. Cows were maintained below $80 \%$ stocking density, assuming 1 headlock or freestall per cow.

Cows were fed twice daily at 0730 and $1530 \mathrm{~h}$. Faroff cows were fed a TMR from dry-off to 2 wk before projected parturition consisting of $4.5 \mathrm{~kg}$ of ryegrass hay, $3.4 \mathrm{~kg}$ of orchardgrass hay, $2.3 \mathrm{~kg}$ of corn silage, and $2.7 \mathrm{~kg}$ of dry cow grain per cow per day. Close-up cows were fed a TMR up to parturition consisting of 3.6 $\mathrm{kg}$ of orchardgrass hay, $1.8 \mathrm{~kg}$ of clover, $11.3 \mathrm{~kg}$ of corn silage, and $3.0 \mathrm{~kg}$ of dry cow grain per cow per day. All cows had ad libitum access to water except exercise treatment cows during exercise.

\section{Experimental Treatments}

Before enrollment, all cows had been housed in the same freestall barn with no previous experience with exercise, aside from pasture access during the dry period before the previous calving. Cows were enrolled into treatments on the day of dry-off. Cows assigned to confinement remained in the pen at all times, except for general management reasons (i.e., cleaning, rebedding stalls) when cows were moved to an adjacent lane for a maximum of $30 \mathrm{~min}$. Cows were permitted to eat, drink, and move around the pen during treatment periods.

Cows assigned to exercise were removed from the pen 5 times/wk, Monday through Friday, and walked for a targeted $1.5 \mathrm{~h}$ at $3.25 \mathrm{~km} / \mathrm{h}$ beginning at $1200 \mathrm{~h}$ along the path denoted by a dashed black line in Figure 1, measuring $250 \mathrm{~m}$ for each lap. Cows were walked in a group using the cows' flight zones and implements (i.e., rattle paddle) to encourage walking. Exercise pace was calculated by the total exercise time divided by the distance walked. During periods of high heat load, de- 
termined subjectively through cow heat stress behavior (i.e., increased respiration rate, panting) and exerciser comfort, cows were offered water at the point where the walking path met the entrance to the milking parlor (Figure 1) from a 19-L bucket. Cows did not have access to feed during the exercise period.

Cows on pasture were moved into a 2.11-ha pasture (Pasture 1) from January to April 2015 and a 0.42-ha pasture (Pasture 2) from April to December 20155 times/wk, Monday to Friday. Different pastures were used during the study based on management factors and proximity to the barn. Pasture 1 was $330 \mathrm{~m}$ from the barn to the pasture gate, and Pasture 2 was $15 \mathrm{~m}$ from the barn to the pasture gate. Pasture 1 had rolling hills and a 0.75 -ha wooded area, and pasture 2 had a shade structure and trees around one side of the fence line. Both pastures were seeded with orchardgrass and KY-31 fescue and managed by the farm manager for a height of 0.3 to $0.5 \mathrm{~m}$. Cows were put on pasture before and returned to the barn after exercising cows from the exercise treatment group. Cows were put on pasture for a target of $1.5 \mathrm{~h}$ beginning at $1200 \mathrm{~h}$. Both pastures had access to water and grass. Time spent grazing and feeding indoors was not measured within this study.

\section{Activity}

Cows were fitted with accelerometers (IceTag, IceRobotics, Edinburgh, UK) 3 d before dry-off, and the accelerometers were removed $14 \mathrm{~d}$ after calving. Activity was summarized by day from dry-off to the day before calving into daily steps (no./d).

\section{Hoof Measures}

Hoof growth and wear and sole thickness were measured on d 2 and 44, relative to dry-off. Cows were moved into a mobile, stand-up leg chute between 1000 and $1100 \mathrm{~h}$ before daily treatments were imposed. Only the rear hooves were measured because rear hooves show greater wear and growth patterns and would display more difference over $42 \mathrm{~d}$ than front hooves (Hahn et al., 1986). To measure hoof growth and wear, each back claw was grooved horizontally and vertically using a power file (Figure 2), according to van Amstel et al. (2016). Grooves were ground at a depth of $1 \mathrm{~mm}$ to ensure grooves did not extend past the hoof wall or fade before the lines were measured at $\mathrm{d} 44$. The first vertical line (line B) was ground parallel to the heel, midway between the heel and toe. The second vertical line (line A) was ground parallel to the heel between the first line and the toe. The horizontal line was ground just below the periople of the coronary band. After grooving, the following measures were taken: coronary band to horizontal line using line B (B1), coronary band to horizontal line using line A (A1), horizontal line to edge of the hoof wall using line B (B2), and horizontal line to the edge of the hoof wall using line A (A2). Line segments were using a ruler (accurate to $0.1 \mathrm{~mm}$ ) on $\mathrm{d}$ 2 and 44 and caudal and cranial growth and wear were calculated using the following calculations (van Amstel et al., 2016):

$$
\begin{aligned}
& \text { Cranial growth }=\mathrm{A} 1(\mathrm{~d} 44)-\mathrm{A} 1 \text { (d 2), } \\
& \text { Caudal growth }=\mathrm{B} 1(\mathrm{~d} 44)-\mathrm{B} 1(\mathrm{~d} 2),
\end{aligned}
$$

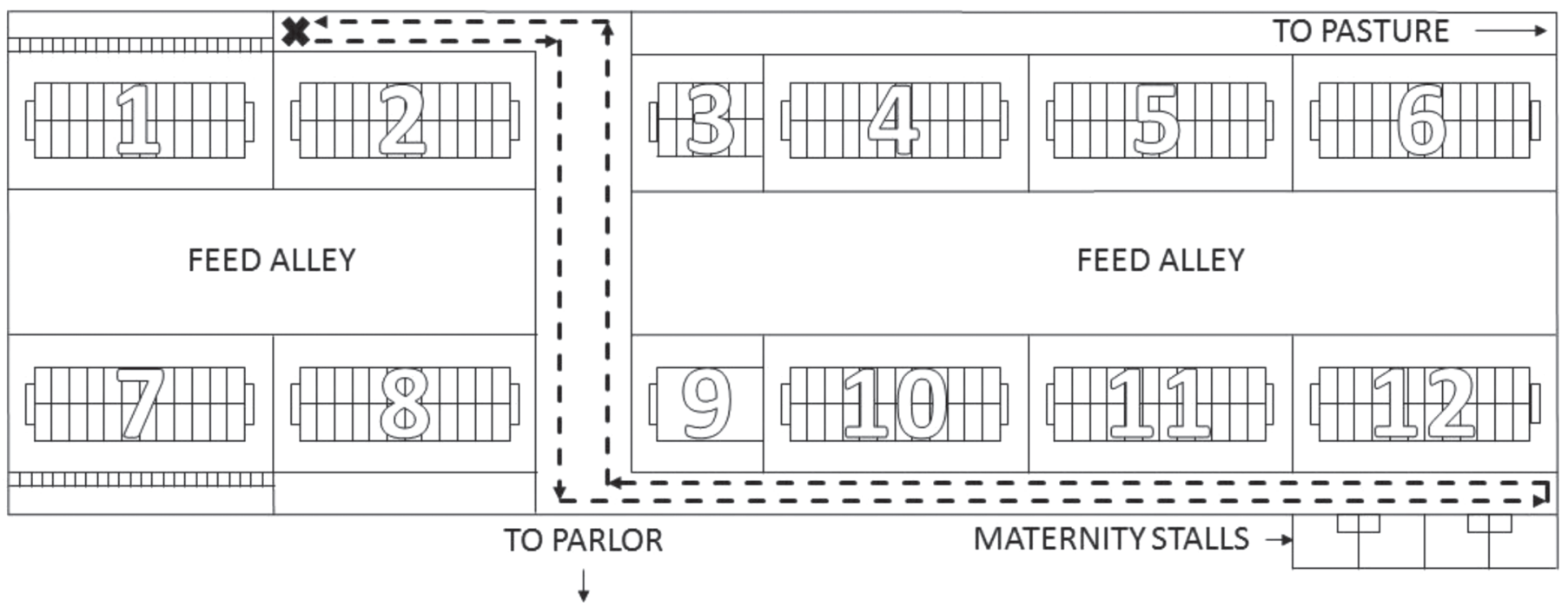

Figure 1. Diagram of University of Tennessee Little River Animal and Environmental Unit freestall barn with the exercise route marked with a dashed line and the start and end location denoted by a black X. The total distance traveled out and back equals $250 \mathrm{~m}$. 

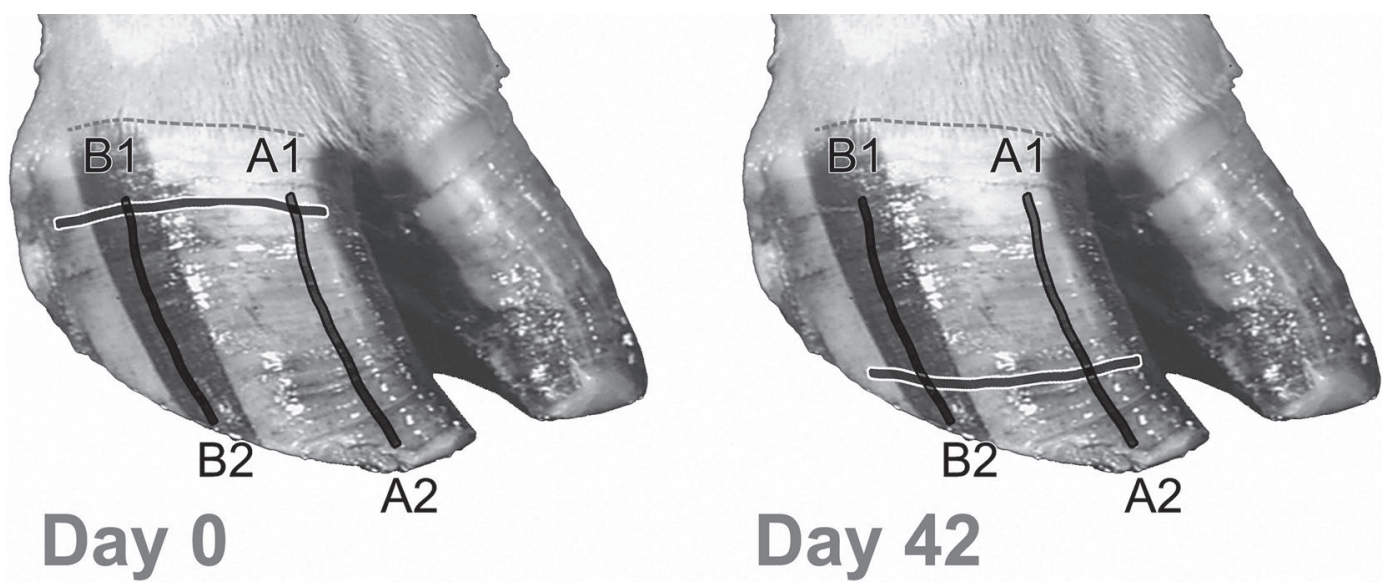

Figure 2. Location of grooves used to measure horn growth and wear (van Amstel et al., 2016). Medical illustrations by D. K. Haines $₫$ 2017, The University of Tennessee.

$$
\begin{gathered}
\text { Cranial wear }=[\text { A1 (d 2) + A2 (d 2) } \\
+ \text { cranial growth }]-[\text { A1 (d 44) }+ \text { A2 (d 44) }], \\
\text { Caudal wear }=[\text { B1 (d 2) + B2 (d 2) } \\
+ \text { caudal growth }]-[\text { B1 (d 44) }+ \text { B2 (d 44) }] .
\end{gathered}
$$

Sole thickness was measured using a $7.0-\mathrm{MHz}$ curvilinear probe on each day, as described by van Amstel et al. (2004). Hooves were cleaned using a brush with water and alcohol applied to the sole to improve probe contact. The probe was placed approximately $3.75 \mathrm{~cm}$ below the apex of the toe and on the inside of the abaxial line (Figure 3). Sole thickness was measured as the area between the outer margin of the ultrasound

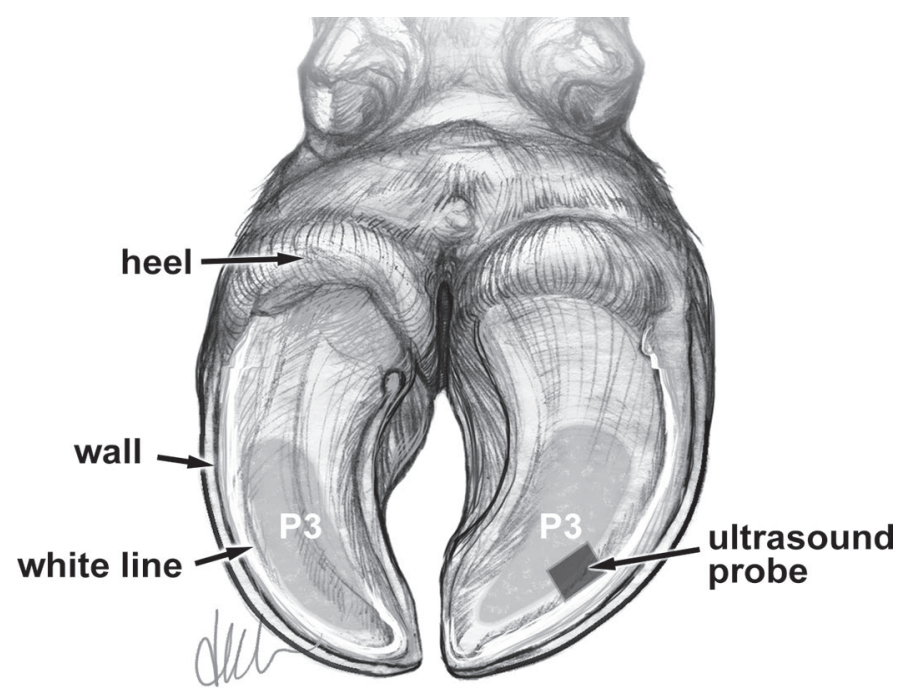

Figure 3. Diagram of ultrasound probe placement to measure sole thickness (van Amstel et al., 2004). Medical illustrations by D. K. Haines ${ }^{\circledR} 2017$, The University of Tennessee. image and the inner sole seen as a thin continuous hyperechoic (Figure 4; Kofler et al., 1999). All 4 rear claws were measured.

\section{Locomotion Scoring}

Cows were scored for locomotion on d 0 and 42, relative to dry-off, using the system by Olmos et al. (2009). Individual scores $(1-5$, where $1=$ normal and $5=$ severely abnormal) for symmetry (symmetry of weight distribution at walk), speed (freedom and ease of movement at walk), head bobbing (marking of the vertical movement during locomotion), spine curvature (degree of spine arching), tracking (length of symmetry of the anterior of and posterior stride phase), and abduction/ adduction (left and right side stride of the swing phase) were averaged to obtain a mean locomotion score. Cows were considered lame with a locomotion score $\geq 3$.

\section{Statistical Analysis}

The experimental and observational units of this study were the cow. Data were analyzed using a mixed linear model (MIXED procedure, SAS 9.4, SAS Inst., Cary, NC). Cow within treatment was considered a random variable. Explanatory variables included treatment (confinement, exercise, pasture) to analyze hoof growth and wear. Sole thickness was analyzed using treatment, day (d 2 and 44), and their interactions as explanatory variables. The difference in sole growth and wear was evaluated using treatment, parameter (growth, wear), and their interactions as explanatory variables. Lameness was evaluated using treatment, day $(\mathrm{d} 0,42)$, and their interaction as explanatory variables. Values presented are least squares means (LSM) \pm standard error of means (SEM) unless otherwise 

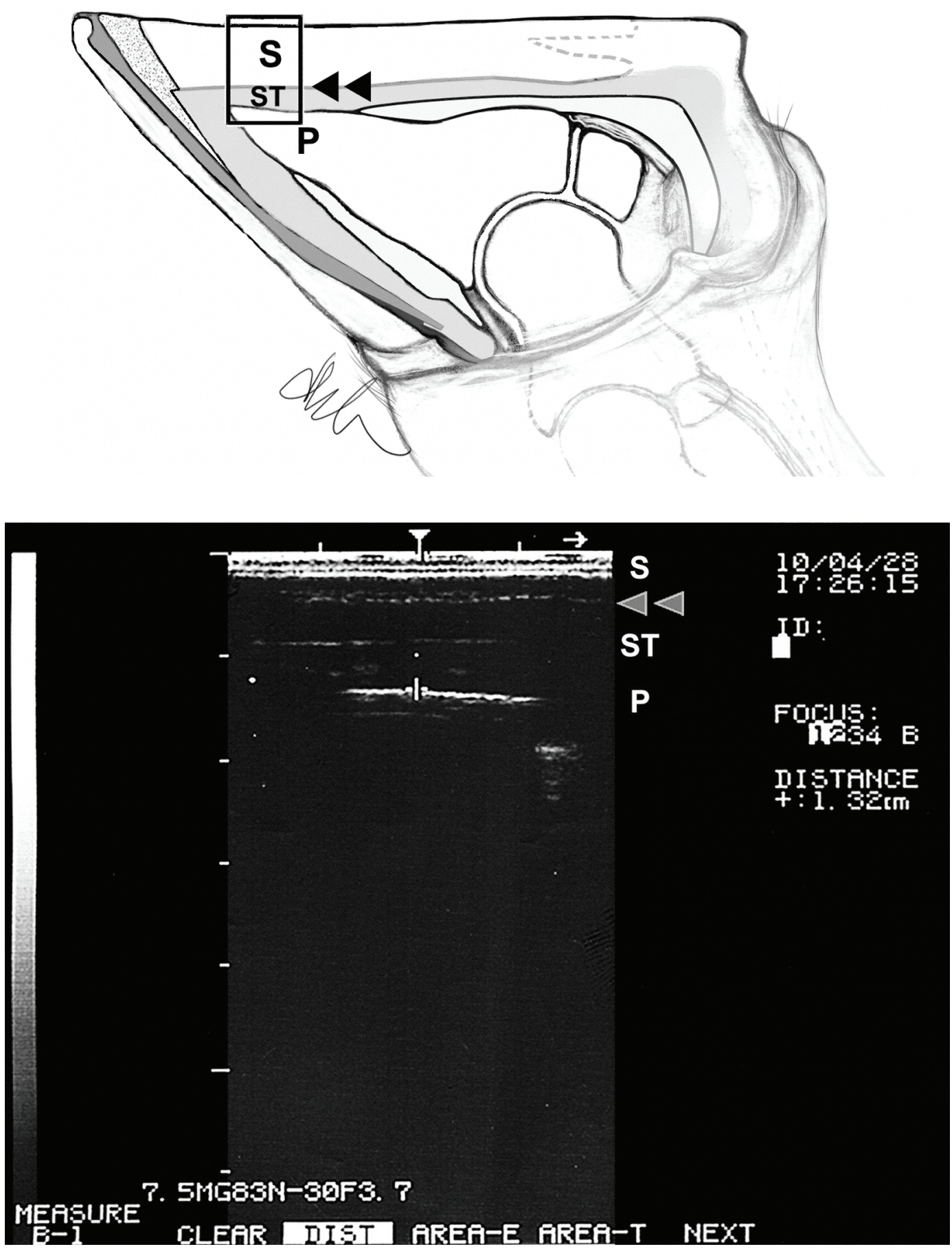

Figure 4. Diagram of longitudinal ultrasound image, where sole thickness is measured from the weight-bearing surface (outer margin of the ultrasound image) to the inner sole (seen as a thin continuous hyperechoic) (van Amstel et al., 2004). The sole horn (S), soft tissue (ST), ventral surface of the third phalanx (P), and inner margin of the sole (double arrow heads) are indicated. Medical illustrations by D. K. Haines ${ }^{\circledR} 2017$, The University of Tennessee.

stated. The Kenward-Roger approximation for distribution of degrees of freedom between fixed effects was used and treatment effects were declared significant at $P \leq 0.05$, while a trend was assumed for probabilities
$P<0.1$ and $P>0.05$. Post hoc means separation for significant main effects was done using Tukey-Kramer's adjustment of probability values. Data normality was evaluated using the UNIVARIATE procedure of SAS. 


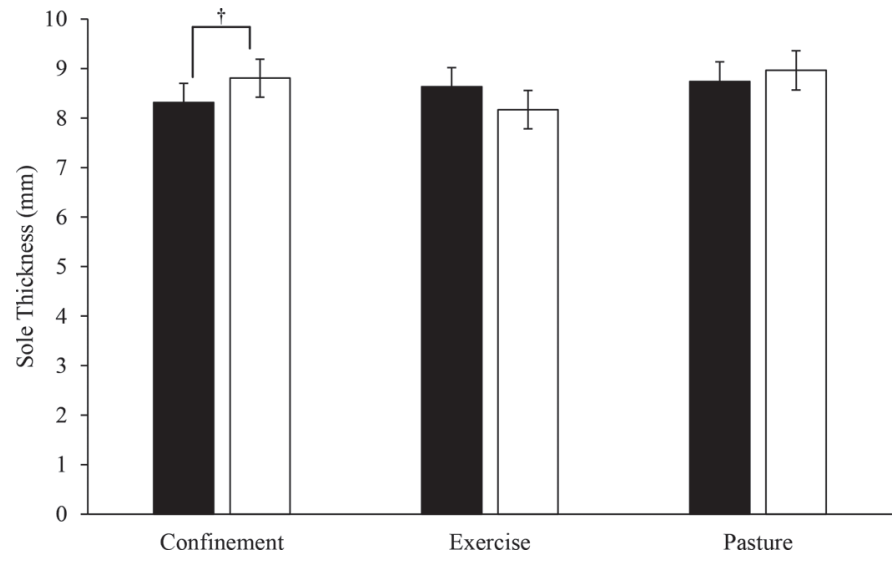

Figure 5. Sole thickness (LSM $\pm \mathrm{SE}$ ) of cows on d 2 (black bars) and d 44 (white bars) relative to dry-off for confined $(\mathrm{n}=19)$ ), exercise $(\mathrm{n}=18)$, and pasture cows $(\mathrm{n}=18)$. $\dagger$ Differ at $P<0.10$.

\section{RESULTS}

Exercise cows walked for a mean $( \pm \mathrm{SD}) 1.4 \pm 0.1$ $\mathrm{h} / \mathrm{d}$ at $1.88 \pm 0.58 \mathrm{~km} / \mathrm{h}$. Pasture cows spent a mean $( \pm \mathrm{SD})$ of $2.0 \pm 0.3 \mathrm{~h} / \mathrm{d}$ on Pasture 1 and $1.7 \pm 0.3$ $\mathrm{h} / \mathrm{d}$ on Pasture 2. Exercise, pasture, and confined cows took a mean $( \pm$ SD) $2,890.6 \pm 1,085.2,2,117.7 \pm 775.6$, and $1,785.7 \pm 791.8$ steps/d, respectively, during the dry period. Five cows were excluded from hoof growth and wear and sole thickness data (confinement $=1$, exercise $=2$, pasture $=2$ ) because the cows' hooves were trimmed before d 42 of the study. Treatment did not affect cranial horn growth $(P=0.40)$ or caudal horn growth $(P=0.20)$. Cranial and caudal horn wear was greater for exercise cows than confined and pasture cows $(P<0.0001$; Table 1$)$. Cranial horn growth was greater than wear in confined $(P<0.0001)$ and pasture cows $(P<0.01)$ but not exercise cows $(P=0.67)$. Horn growth and wear did not differ caudally by treatment $(P=0.31)$, but horn growth was greater than horn wear (1.09 vs. $0.84 \mathrm{~mm}$, respectively; $P<0.0001$; Table $1)$. Sole thickness tended to be affected by treatment $x$ day $(P=0.07$; Figure 5$)$, with confined cows tending to have increased sole thickness from d 2 to d 44. Locomotion score was not affected by treatment (confinement: $1.6 \pm 0.1$, exercise: $1.5 \pm 0.1$, pasture: $1.6 \pm 0.1 ; P=$ 0.91 ), day (d 0: $1.5 \pm 0.1$, d 42: $1.6 \pm 0.1 ; P=0.34$ ), treatment $\times$ day $(P=0.93)$.

\section{DISCUSSION}

This study is the first to examine the effect of physical activity on concrete or on pasture on hoof growth and wear and sole thickness. Exercise cows experienced a more even rate of horn growth and wear. Confined cows tended to increase sole thickness throughout the course of the dry period. Treatment did not affect locomotion score.

Horn growth rates have been shown to be seasonal, particularly growing faster in the spring-summer period (Vermunt and Greenough, 1995), greater with higher energy diets (Greenough et al., 1990), and greater in young animals than in older animals (Vermunt and Greenough, 1995). Further, caudal horn growth rate tends to be faster than cranial horn growth (Vermunt and Greenough, 1995), which was noted in the current study with numerically higher values caudally compared with cranially. In the current study, all cows were balanced on parity and were enrolled into treatments throughout the year evenly, indicating that horn growth should be similar between treatments. Pasture cows did have access to grazing on pasture, which may have altered intake of TMR within the barn. Lactating cows offered free-choice pasture access reduced TMR intake by $14 \%$ (Legrand et al., 2009). Restricting pasture access from full access to 2 periods of $3 \mathrm{~h}$ led to increased intake per minute and intake per bite and thus increased grazing efficiency in lactating cows (Kennedy et al., 2009). However, cows in the current study were nonlactating and consumed low-energy diets. The dry period is characterized by a reduction in DMI in a barn and on pasture (Grant and Albright, 1995; Gibb et al.,

Table 1. Horn growth and wear (LSM $\pm \mathrm{SE}$ ) from d 2 and 44 relative to dry-off for confined $(\mathrm{n}=19)$, exercise $(\mathrm{n}=18)$, and pasture cows $(\mathrm{n}=18)$

\begin{tabular}{lccc}
\hline & & Treatment \\
\cline { 2 - 3 } Horn location & Confinement & Exercise & Pasture \\
\hline Cranial & $0.97 \pm 0.08^{\mathrm{x}}$ & $1.11 \pm 0.08^{\mathrm{x}}$ & $0.97 \pm 0.08^{\mathrm{x}}$ \\
$\quad$ Growth $(\mathrm{mm})$ & $0.69 \pm 0.06^{\mathrm{b}, \mathrm{y}}$ & $1.08 \pm 0.06^{\mathrm{a}, \mathrm{x}}$ & $0.76 \pm 0.06^{\mathrm{b}, \mathrm{y}}$ \\
Wear $(\mathrm{mm})$ & & $1.23 \pm 0.10$ & $1.01 \pm 0.10$ \\
Caudal & $1.02 \pm 0.09$ & $1.05 \pm 0.06^{\mathrm{a}}$ & $0.77 \pm 0.05^{\mathrm{b}}$ \\
Growth (mm) & $0.69 \pm 0.05^{\mathrm{b}}$ & & \\
Wear (mm) & & \\
${ }_{\mathrm{a}, \mathrm{b}}$ Denotes a difference within a row at $P<0.05$. & \\
${ }_{\mathrm{x}, \mathrm{y}}$ Denotes a difference within a horn location and between treatments at $P<0.05$. &
\end{tabular}


1999), and nightly pasture access resulted in no alteration in feed intake (Chapinal et al., 2010). The short period of time on pasture likely did not alter TMR intake, particularly because the pasture was not managed for maintenance of lactation. Therefore, although measurement of DMI at both sites would add interesting insight into the effect of diet and exercise of hoof parameters, it likely did not contribute to the growth effects noted.

Alternatively, higher rates of horn wear were associated with concrete flooring, overstocking, poor cow comfort, claw horn moisture, poor stockmanship, and poor horn quality (van Amstel et al., 2002). Because exercise cows experienced more time walking on concrete and took numerically more steps than confined and pasture cows, this group would be expected to also experience the greatest level of wear. Positive implications of increased wear include prevention of toe overgrowth and maintenance of the weight-bearing axis. As toes become overgrown, the weight-bearing axis shifts to the heel and can lead to bruising, hemorrhage, and sole ulceration (Shearer and van Amstel, 2001). However, if cows maintain increased wear from exercise on concrete, excessive wear may result. Increased wear can lead to short toes, reducing sole thickness and shifting the weight-bearing axis to the toe, causing toe ulcers (Shearer and van Amstel, 2001). Therefore, although a short period of exercise on an abrasive surface, such as concrete, may produce some positive benefits, extended periods may lead to negative consequences.

Exercise cows experienced a more even horn growth and wear rate compared with confined and pasture cows. Normal claws are characterized by equal rates of growth and wear (Vermunt and Greenough, 1995), and an imbalance can cause horn lesions (Bazeley and Pinsent, 1984; Greenough and Vermunt, 1991; Cook et al., 2004). Increased horn growth and wear can occur when housed on concrete compared with a softer surface, such as a rubber mat (Vanegas et al., 2006; Telezhenko et al., 2009; van Amstel et al., 2016). The current study, however, determined that regular exercise of cows on concrete contributed to an improved growth and wear rate of the horn, potentially improving hoof health. This finding is in contrast to previous research indicating improved hoof characteristics and health with access to pasture or a straw yard (Hahn et al., 1986; Somers et al., 2003; Chapinal et al., 2010). This outcome may indicate that, during the dry period, additional locomotor activity on a concrete surface does not impair the hoof health of cows. However, it should be noted that the current study did not record hoof disorders, such as horn lesions, white line disease, or other disorders caused by environmental factors, and additional work looking at hoof disorders is needed to fully understand the interaction of exercise and hoof health.

Walking on concrete has been previously associated with thin soles (van Amstel et al., 2006). Soles provide protection to the claw capsule (Toussaint Raven, 1989), and thin soles are more prone to injury and contusion, particularly in environments with hard or irregular surfaces (Greenough, 1987; Toussaint Raven, 1989). It should be noted that exercise cows experienced a numerical reduction in sole thickness, although it was not statistically significant. This reduction may be due to the increased wear experienced with exercise, which can lead to the thinning of soles (Shearer and van Amstel, 2001), further demonstrating that prolonged exercise on concrete may lead to negative consequences. Alternatively, pasture cows did not experience a reduction in sole thickness, whereas confined cows had a tendency to increase sole thickness, illustrating that the pasture regimen and total confinement did not have a negative effect on hoof health. However, all cows were above the minimum of $7 \mathrm{~mm}$ to provide adequate protection to the claw capsule (Toussaint Raven, 1989).

The implementation of exercise into a management system may be important beyond measurements reported in this study. As a cow walks, the movement acts as a pumping mechanism by squeezing vessels between the wall and distal phalanx and pumping blood from the claw back into circulation (Greenough, 2007). This process helps provide nutrients and oxygen to the hoof tissues and is especially important in transition cows when horn quality is weakened from systematic changes with calving and lactogenesis, increasing the likelihood of white line disease and horn lesions (Kempson and Logue, 1993; Webster, 2001). However, it is important that cows do not perform excessive exercise on concrete, which could lead to an imbalance in growth and wear and subsequent hoof health consequences (Bazeley and Pinsent, 1984; Greenough and Vermunt, 1991; Cook et al., 2004).

Realistically, exercise in this form on a commercial dairy would not be feasible because of time and labor restrictions. A form of pasture access that does not require intense pasture management and also encourages cows to explore the paddock and move throughout the pen may be a more optimal recommendation. However, as noted with this study, pasture cows did not engage in much more walking than confined cows, indicating that, as implemented in this study, pasture access does not encourage activity. However, allowing pasture access during periods when cows are more likely to graze (Walker et al., 2008) and prefer to be on pasture (Legrand et al., 2009), such as evening hours, may promote increased physical activity. Adding important or novel resources, such as water, brushes, feed supplements, 
and calves or heifers in an adjacent pen, at locations requiring more locomotor activity to reach may also encourage more physical activity.

\section{CONCLUSIONS}

Exercise cows experienced greater hind hoof horn wear than confined and pasture cows but had more equal rates of horn growth and wear. Sole thickness was not altered with exercise or pasture turnout but tended to increase for cows in total confinement, and all cows remained above the minimum thickness to provide adequate protection to the claw capsule. Frequent access to exercise on concrete may not impair the hoof health of late-gestation dry cows.

\section{ACKNOWLEDGMENTS}

The authors thank Holly Evens, Lindsay Wick, and Kala Kyker for assistance during sample collection. We also thank Charlie Young, Mark Lewis, and the University of Tennessee LRAEU staff for support throughout the study. This research was supported by USDA Hatch.

\section{REFERENCES}

Bazeley, K., and P. J. Pinsent. 1984. Preliminary observations on a series of outbreaks of acute laminitis in dairy cattle. Vet. Rec. 115:619-622. https://doi.org/10.1136/vr.115.24.619.

Black, R. A., and P. D. Krawczel. 2016. A case study of behaviour and performance of confined or pastured cows during the dry period. Animals (Basel) 6:E41. https://doi.org/10.3390/ani6070041.

Booth, C. J., L. D. Warnick, Y. T. Gröhn, D. O. Maizon, C. L. Guard, and D. Janssen. 2004. Effect of lameness on culling in dairy cows. J. Dairy Sci. 87:4115-4122. https://doi.org/10.3168/jds.S0022 -0302(04)73554-7.

Burow, E., P. T. Thomsen, T. Rousing, and J. T. Sørensen. 2014. Track way distance and cover as risk factors for lameness in Danish dairy cows. Prev. Vet. Med. 113:625-628. https://doi.org/10 .1016/j.prevetmed.2013.11.018.

Chapinal, N., C. Goldhawk, A. M. de Passillé, M. A. G. von Keyserlingk, D. M. Weary, and J. Rushen. 2010. Overnight access to pasture does not reduce milk production or feed intake in dairy cattle. Livest. Sci. 129:104-110. https://doi.org/10.1016/j.livsci 2010.01.011.

Cook, N. B., and K. V. Nordlund. 2009. The influence of the environment on dairy cow behavior, claw health and herd lameness dynamics. Vet. J. 179:360-369. https://doi.org/10.1016/j.tvj1.2007 .09 .016 .

Cook, N. B., K. V. Nordlund, and G. R. Oetzel. 2004. Environmental influences on claw horn lesions associated with laminitis and subacute ruminal acidosis in dairy cows. J. Dairy Sci. 87(E. Suppl.):E36-E46. https://doi.org/10.3168/jds.S0022 -0302(04)70059-4.

Gibb, M. J., C. A. Huckle, R. Nuthall, and A. J. Rook. 1999. The effect of physiological state (lactating or dry) and sward surface height on grazing behaviour and intake by dairy cows. Appl. Anim. Behav. Sci. 63:269-287. https://doi.org/10.1016/S0168 -1591(99)00014-3.

Grant, R. J., and J. L. Albright. 1995. Feeding behavior and management factors during the transition period in dairy cattle. J. Anim. Sci. 73:2791-2803. https://doi.org/10.2527/1995.7392791x.
Green, L. E., V. J. Hedges, Y. H. Schukken, R. W. Blowey, and A. J. Packington. 2002. The impact of clinical lameness on the milk yield of dairy cows. J. Dairy Sci. 85:2250-2256. https://doi.org/10 $.3168 /$ jds.S0022-0302(02)74304-X.

Greenough, P. R. 1987. Pododermatitis circumscripta (ulceration of the sole) in cattle. Agric-Practice Nov./Dec.:17-22.

Greenough, P. R. 2007. Microstructure and function of the bovine claw. Pages 8-28 in Bovine Laminitis and Lameness: A Hands-on Approach. C. Bergsten, A. Brizzi, C. K. W. Mülling, and K. Nordlund, ed. W. B. Saunders, Edinburgh, UK.

Greenough. P. R., and J. J. Vermunt. 1991. Evaluation of subclinical laminitis in a dairy herd and observations on associated nutritional and management factors. Vet. Rec. 128:11-17. https://doi.org/10 $.1136 / v r .128 .1 .11$.

Greenough, P. R., J. J. Vermunt, J. J. McKinnon, F. A. Fathy, P. A. Berg, and R. D. H. Cohen. 1990. Laminitis-like changes in the claws of feedlot cattle. Can. Vet. J. 31:202-208.

Hahn, M. V., B. T. McDaniel, and J. C. Wilk. 1986. Rates of hoof growth and wear in Holstein cattle. J. Dairy Sci. 69:2148-2156. https://doi.org/10.3168/jds.S0022-0302(86)80647-6.

Hernandez-Mendo, O., M. A. G. von Keyserlingk, D. M. Veira, and D. M. Weary. 2007. Effects of pasture on lameness in dairy cows. J. Dairy Sci. 90:1209-1214. https://doi.org/10.3168/jds.S0022 -0302(07)71608-9.

Kempson, S. A., and D. N. Logue. 1993. Ultrastructural observations of hoof horn from dairy cows: Changes in the white line during the first lactation. Vet. Rec. 132:524-527. https://doi.org/10.1136/vr .132.21.524.

Kennedy, E., M. McEvoy, J. P. Murphy, and M. O'Donovan. 2009. Effect of restricted access time to pasture on dairy cow milk production, grazing behavior, and dry matter intake. J. Dairy Sci. 92:168-176. https://doi.org/10.3168/jds.2008-1091.

Kofler, J., P. Kübber, and W. Henninger. 1999. Ultrasonographic imaging and thickness measurement of the sole horn and the underlying soft tissue layer in bovine claws. Vet. J. 157:322-331. https:// doi.org/10.1053/tvjl.1998.0315.

Kossaibati, M. A., and R. J. Esslemont. 1997. The costs of production diseases in dairy herds in England. Vet. J. 154:41-51. https://doi .org/10.1016/s1090-0233(05)80007-3.

Legrand, A. L., M. A. G. von Keyserlingk, and D. M. Weary. 2009. Preference and usage of pasture versus free-stall housing by lactating dairy cattle. J. Dairy Sci. 92:3651-3658. https://doi.org/10 $.3168 /$ jds.2008-1733.

Loberg, J., E. Telezhenko, C. Bergsten, and L. Lidfors. 2004. Behaviour and claw health in tied dairy cows with varying access to exercise in an outdoor paddock. Appl. Anim. Behav. Sci. 89:1-16. https://doi.org/10.1016/j.applanim.2004.04.009.

Olmos, G., L. Boyle, B. Horan, D. P. Berry, P. O'Connor, J. F. Mee, and A. Hanlon. 2009. Effect of genetic group and feed system on locomotion score, clinical lameness and hoof disorders of pasturebased Holstein-Friesian cows. Animal 3:96-107. https://doi.org/ 10.1017/S1751731108003248.

Politiek, R. D., O. Distl, T. Fjeldaas, J. Heeres, B. T. McDaniel, E. Nielsen, D. J. Peterse, A. Reurink, and P. Strandberg. 1986. Importance of claw quality in cattle: Review and recommendations to achieve genetic improvement. Report of the E.A.A.P. working group on "claw quality in cattle". Livest. Prod. Sci. 15:133-152. https://doi.org/10.1016/0301-6226(86)90023-0.

Ranjbar, S., A. R. Rabiee, A. Gunn, and J. K. House. 2016. Identifying risk factors associated with lameness in pasture-based dairy herds. J. Dairy Sci. 99:7495-7505. https://doi.org/10.3168/jds .2016-11142.

Shearer, J. K., M. L. Stock, S. R. van Amstel, and J. F. Coetzee. 2013. Assessment and management of pain associated with lameness in cattle. Vet. Clin. North Am. Food Anim. Pract. 29:135-156. https://doi.org/10.1016/j.cvfa.2012.11.012.

Shearer, J. K., and S. R. van Amstel. 2001. Functional and corrective claw trimming. Vet. Clin. North Am. Food Anim. Pract. 17:53-72. https://doi.org/10.1016/S0749-0720(15)30054-2.

Smit, H., B. Verbeek, D. J. Peterse, J. Jansen, B. T. McDaniel, and R. D. Politiek. 1986. Genetic aspects of claw disorders, claw measure- 
ments and 'type' scores for feet in Friesian cattle. Livest. Prod. Sci. 15:205-217. https://doi.org/10.1016/0301-6226(86)90030-8.

Sogstad, A. M., T. Fjeldaas, and O. Osteras. 2005. Lameness and claw lesions of the Norwegian red dairy cattle housed in free stalls in relation to environment, parity and stage of lactation. Acta Vet. Scand. 46:203-217.

Solano, L., H. W. Barkema, E. A. Pajor, S. Mason, S. J. LeBlanc, J. C. Zaffino Heyerhoff, C. G. R. Nash, D. B. Haley, E. Vasseur, D. Pellerin, J. Rushen, A. M. de Passillé, and K. Orsel. 2015. Prevalence of lameness and associated risk factors in Canadian HolsteinFriesian cows housed in freestall barns. J. Dairy Sci. 98:6978-6991. https://doi.org/10.3168/jds.2015-9652.

Somers, J. G., K. Frankena, E. N. Noordhuizen-Stassen, and J. H. M. Metz. 2003. Prevalence of claw disorders in Dutch dairy cows exposed to several floor systems. J. Dairy Sci. 86:2082-2093. https:// doi.org/10.3168/jds.S0022-0302(03)73797-7.

Telezhenko, E., C. Bergsten, M. Magnusson, and C. Nilsson. 2009. Effect of different flooring systems on claw conformation of dairy cows. J. Dairy Sci. 92:2625-2633. https://doi.org/10.3168/jds.2008 -1798 .

Toussaint Raven, E. 1989. Structure and function. Pages 24-26 in Cattle Foot Care and Claw Trimming. Farming Press, Ipswich. UK.

USDA. 2010. Facility characteristics and cow comfort on U.S. dairy operations, 2007. USDA-APHIS-VS, CEAH, Fort Collins, CO.

USDA. 2016. Dairy cattle management practices in the United States, Dairy 2014. USDA-APHIS-VS, CEAH, Fort Collins, CO.

van Amstel, S., C. Young, C. Scully, and B. Rohrbach. 2016. Rate of horn growth, wear and sole thickness of dairy cattle in a free stall barn with concrete and rubber flooring. J. Dairy Vet. Anim. Res. 4:00120 https://doi.org/10.15406/jdvar.2016.04.00120.

van Amstel, S. R., F. L. Palin, J. K. Shearer, and B. Robinson. 2002. Anatomical measurement of sole thickness in cattle following two different trimming techniques. Bovine Pract. 36:136-140.

van Amstel, S. R., J. K. Shearer, and F. L. Palin. 2004. Moisture content, thickness, and lesions of sole horn associated with thin soles in dairy cattle. J. Dairy Sci. 87:757-763. https://doi.org/10.3168/ jds.S0022-0302(04)73219-1.

van Amstel, S. R., J. K. Shearer, F. L. Palin, J. Cooper, and G. Rodgers. 2006. The effect of parity, days in milk, season and walking surface on thin soles in dairy cattle. Pages 142-143 in Proc. 14th Int. Symp. 6th Conf. on Lameness in Ruminants, Colonia del Sacremento, Uruguay.

Vanegas, J., M. Overton, S. L. Berry, and W. M. Sischo. 2006. Effect of rubber flooring on claw health in lactating dairy cows housed in free-stall barns. J. Dairy Sci. 89:4251-4258. https://doi.org/10 .3168/jds.S0022-0302(06)72471-7.

Vermunt, J. J., and P. R. Greenough. 1995. Structural characteristics of the bovine claw: Horn growth and wear, horn hardness and claw conformation. Br. Vet. J. 151:157-180. https://doi.org/10.1016/ S0007-1935(95)80007-7.

von Keyserlingk, M. A. G., A. Barrientos, K. Ito, E. Galo, and D. M. Weary. 2012. Benchmarking cow comfort on North American freestall dairies: Lameness, leg injuries, lying time, facility design, and management for high-producing Holstein dairy cows. J. Dairy Sci. 95:7399-7408. https://doi.org/10.3168/jds.2012-5807.

von Keyserlingk, M. A. G., J. Rushen, A. M. de Passillé, and D. M. Weary. 2009. Invited review: The welfare of dairy cattle-Key concepts and the role of science. J. Dairy Sci. 92:4101-4111. https:// doi.org/10.3168/jds.2009-2326.

Walker, S. L., R. F. Smith, J. E. Routly, D. N. Jones, M. J. Morris, and H. Dobson. 2008. Lameness, activity time-budgets, and estrus expression in dairy cattle. J. Dairy Sci. 91:4552-4559. https://doi .org/10.3168/jds.2008-1048.

Warnick, L. D., D. Janssen, C. L. Guard, and Y. T. Gröhn. 2001. The effect of lameness on milk production in dairy cows. J. Dairy Sci 84:1988-1997. https://doi.org/10.3168/jds.S0022-0302(01)74642 -5 .

Webster, A. J. 2001. Effects of housing and two forage diets on the development of claw horn lesions in dairy cows at first calving and in first lactation. Vet. J. 162:56-65. https://doi.org/10.1053/tvjl 2001.0569.

Wells, S. J., L. P. Garber, and B. A. Wagner. 1999. Papillomatous digital dermatitis and associated risk factors in US dairy herds. Prev Vet. Med. 38:11-24. https://doi.org/10.1016/S0167-5877(98)00132 $-9$.

Whay, H. R., A. E. Waterman, A. J. F. Webster, and J. K. O'Brien. 1998. The influence of lesion type on the duration of hyperalgesia associated with hindlimb lameness in dairy cattle. Vet. J. 156:2329. https://doi.org/10.1016/S1090-0233(98)80058-0. 